\title{
THE OVERGOD.
}

\author{
"Was man von Gott gesagt, \\ Das g'nüget mir noch nicht: \\ Die Ueber-Gottheit ist \\ Mein Leben und mein Licht." \\ -Angelus Silesius, I, 15.
}

$\mathrm{W}$

HEN I was still a child I knew my God.

The mighty ruler of the Universe

Looked down on me and shaped my destiny

With loving fatherly concern. I trusted

In both his wisdom and benevolence,

I felt his presence and kind dispensation

In mine own heartbeat and in every thought

That pulsed through mine own mind, and I would wonder

At all the grandeur of God's great creation.

Such was my faith when I was still a child.

But childhood passed, and I saw more of life;

I saw the bad triumphant o'er the good,

I saw the noble suffer and the vile

Laugh viciously at virtue's sad defeat.

Doubt came to me, but I tenaciously

Would cling to Him, my God! I knew that firmly

I would believe e'en though his non-existence

By every science would be demonstrated.

My faith, heroically militant,

Was strong enough to be invincible. 
I saw the law and order in the world:

Should I not bow to Him who made the law?

And where I witnessed merit unrewarded And wrong triumphant, I would trust that God Doles out his justice in another world.

A childlike faith in God is beautiful!

It leads through life so well, so easily, It makes us confident to do the right: And I was yearning to preserve my faith. I needed God and thus prayed fervently: "O God, my God, do not depart from me! God, leave me not!" E'en then my faith was fading.

Oppressive thoughts came over me! I argued: "O God, thy laws are mightier than thyself! Who made the simple rule, 'Twice two is four'? Who made the laws? Are they not sternly rigid? Are they not, like arithmetic, results Which must be as they are? I understand That other than they are they cannot be. They are immutable and immanent, They are for all eternity the same. Aye, God himself could never change their truth!

O God, my God, the problem is too deep. Come to my rescue, come to guide my soul Through this entangling labyrinth of doubt!"

Doubt grew and took possession of my soul: "Where art thou, God? Give answer unto me. Oh speak to me and say how I shall find thee; Oh tell me truly whether thou existest!"

In my anxiety of doubt I waited In vain for answer. I consoled myself 
By saying, "God no longer speaks to men. He speaks to children in a childlike way, But not to men, not to the scientists." And does this mean that God is merely fancy, A dream of poetry, a fond illusion?

If that be so, well, why not face the truth?

Cease being child and rise to man's estate.

If this our universe is void and drear,

If it is meaningless and has no God,

Dare know the facts hard though they be, and dare Confront this stolid, soulless, huge machine. Avoid its cogs and wheels and learn to use The power which it contains. Boldly set sail To winds that blow, take helm in hand and steer Thy ship to reach the other longed for shore.

Be independent, shape thy destiny

With foresight, quit all superstitious awe,

Dismiss false fear of deities and devils.

Yea I myself must be my God and master.

I'll be a man, I'll fight the battle bravely,

I must adapt myself to my surroundings

And also my surroundings to myself.

I'll be no longer slave, I'll take the lead, And atheism shall the emblem be

Of the dear freedom which my soul has gained.

So we are free, no God rules over us, No tyrant holds us in subjection! Yea, The One whom we have feared, whom tremblingly We loved, revered and worshiped, full of awe, Has passed away. He died and lives no more. $\mathrm{He}$ is a shadow of his former power, And we are here to lead our lives ourselves In liberty, with pride of independence, 
And on our own responsibility.

Our boldest self-conceit is justified, And we have thus attained the highest glory.

And yet, proud man, consider thou hast reached This eminence by working out thy reason, By broadening thy knowledge and by gaining A comprehension of the universe.

Remember, thou hast traced the laws of nature And thou hast found there is both truth and error, And men may follow either of the twain. Wisdom there is, and folly, right and wrong. Here takest thou thy stand in this wide world To choose the way in which thou wouldest live, And blest art thou if noble be thy choice. Brief is thy span of life; vain are the pleasures Which would decoy thee to a worthless life. But by an honest effort mayest thou Attain the realm of the eternal law. Thou seest the features that remain the same, The uniformities that make the world A well-ordained and regulated cosmos.

These uniformities when understood Are unavoidable necessities;

They are the same as that "twice two makes four." And they, so simple, so self-evident, Furnish the key that will unlock life's problems. The norm of truth they are, of right and wrong, And they shall serve thee as thy guide in life. Yet all these norms, these eternalities, These many laws of nature, are but one,One and the same in different applications, One and One only, and this One alone, This one necessity rules all the world, 
Our own and other worlds, the known, the unknown, All real worlds, all that are possible;

All things that are or might be must conform

To absolute consistency, to rules

Described by thought-norms and in number-lore,

To rules mechanical and necessary.

Laws are but uniformities and mean

That sameness of condition brings about

A sameness of result. We state the facts

In formulas and call them laws of nature;

But we must search to find and comprehend them,

To understand their stern consistency,

And universal sway. Never were they

Begotten and they never shall not be.

They are eternal, their validity

Is infinite, and if the world break down,

If nature should flash up and be dissolved,

They still hold good, their rule shall never cease.

They are above all nature, everlasting,

Immutable, and range above all gods.

Yea, if there were a God and he would venture

To build up worlds, he needs must heed these laws:

They are above him, they are higher than

His true or merely fancied sovereign rule.

Though they seem naught, they are omnipotent,

More veritable, more immutable

And more eternal, they are more divine

Than He, the God of our first childhood days:

They are the Overgod, the higher God.

Is it the Overgod for whom I yearned, Whom I believed that I did comprehend When once in childhood I believed in God? 
Is He perchance the true and only God?

Yea, $\mathrm{He}$ alone is verily eternal;

He sways the world with wondrous immanence;

Yet $\mathrm{He}$ is truly supernatural,

His thoughts are not like thoughts of mortal beings;

They are not temporal, are not a process

Of coming down from premise to conclusion

In tame successive arguments. His thoughts

Are the eternal glorious laws of nature

Which ever were and ever will remain

To all eternity, world without end,

Parts of Himself, parts of the Overgod

And of the Overgod's divinity.

My God, I now discern thou art not mute, Thou speakest to thy children. If they ask thee

In the right spirit thou wilt answer give;

If they with due discretion search for truth, They finally shall find it, and the truth

Alone is God's eternal revelation.

'T is truth in which God speaks, and God's great truth

Speaks clear and constant in the Still Small Voice.

God of my childhood, thou didst fade away,

But I discovered thee again. I found

The God of truth, the Overgod, and now

It dawns on me that thou art He Himself.

There is but one true God-the Overgod;

And thou, God of my childhood, wast a promise,

An image and poetic allegory,

A prophecy and a presentiment,

A child's conception of a greater truth.

Truly the God of law is not a fable;

$\mathrm{He}$ is not matter, is not energy, 
Nor to the senses is discernible;

But he is more than body, more than power.

$\mathrm{He}$ is not individual nor person;

$\mathrm{He}$ is much more than things or any beings

Of limitation such as move in space.

$\mathrm{He}$ is the factor which creates all things,

Which shapes the world and which begets all order;

$\mathrm{He}$ is the lawdom of the universe;

$\mathrm{He}$ is the norm of rationality

And thereby $\mathrm{He}$ creates the prototype

Of beings that can reason, that can think,

That are responsible for what they do.

He has created personality,

Yet He Himself, the Supernatural,

Is more than personal. The Overgod

Is higher than an individual

And more than any ego. In His image

Egos originate and they reflect

In their minds' mirror His divinity,

The wondrous reason of the cosmic order.

Oh God of law, God of necessity,

Thou cause of evolution and of progress!

Thou buildest up mankind and leadest us

Higher and ever higher. God, my God,

Oh Overgod, thou art the great fulfilment

Of my belief in God. Thou art much higher,

Yet thou art still the same, the selfsame God.

We sink before thee in the dust, and thee,

Great Overgod, we worship on our knees

In deep humility and reverence.

In awe I fell prostrate upon the ground, But God, the Overgod, spake thus to me:

"Rise up and crawl not wormlike in the dust. 
$I$ led thee into freedom and want man

To stand erect before me as my son,

Erect and upright, straight as I have made him,

Not as a slave in cringing attitude.

Tyrants delight in groveling adulation;

So do the gods of savages, not I,

Thy God, the God of truth, the Overgod.

"I live not in the fire, nor in the storm,

But in the still small voice thou findest me.

I want no praise, I dislike supplication,

I hate a bloody sacrifice, and truly

I do despise the unctuous cant of priests.

But I will honor noble freeborn children

Who stand erect and worship me aright.

True worship is not done in flattery

With tongue and lip; acceptable to me

Is homage from the heart and righteous will.

True worship is right thinking and right doing,

Leading a life on earth as son of mine,

Of God thy Father, of the God of Truth." 